\title{
FESTIVAL BAKERY PRODUCTS USING HEAT STABILIZED RICE BRAN
}

\author{
(Received: 28.10. 2014)
}

\author{
By \\ M. H. Abd El-Kader
}

\author{
Bread and Pastries Research Department, Food Technology Research Institute, Agricultural \\ Research Center, Giza, Egypt.
}

\begin{abstract}
In the present study, both of Kahk El-Eid and Petit-four were prepared from wheat flour with heatstabilized rice bran (SRB) at 10, 20 and 30\% replacement levels. Stabilized rice bran by heating represents good sources for nutrients such as fat, protein, fiber, minerals, vitamins and antioxidants. Most of nutrients were concentrated in fine fractions (lower than $400 \mu \mathrm{m}$ ). These fractions can be used to prepare Kahk El-Eid and Petit-four with nutritive advantage since Egyptians consume large amounts in their festival. Kahk El-Eid and Petit-four prepared from wheat flour with 10, 20 and 30\% of heat-stabilized rice bran contained higher nutrients than the control. The sensory evaluation showed that it can replace wheat flour by heat-stabilized rice bran up to $10 \%$ without noticeable differences for Kahk El-Eid, and up to $20 \%$ with a little difference for Petit-four for their sensory characters. The specific volume values were decreased for Kahk El-Eid samples, and the hardness values increased with increasing the replacement levels of SRB. While, both parameters increased for Petit-four samples as replacement levels by SRB increased.
\end{abstract}

Key words: festival bakery products, Kahk El-Eid, Petit-four, stabilized rice bran.

\section{INTRODUCTION}

Festival bakery products with delicious flavor such as biscuits, cakes, pies, pastries, muffins, some kinds of bread and pizza are prepared in occasions all over the world. In Egypt, cookies called Kahk El-Eid and biscuits called Petit-four are prepared in Eid Al-Fitr (Festival of Breaking the Fast) after Ramadan fasting month where, Egyptians consume them in large amounts. Egyptians either bake them at home or buy it from the bakery. Therefore, there is a need to find the ingredients used in bakery products with beneficial nutritive to improve the nutritional quality of the baked products.

The main components of festival bakery products are flour, butter, sugar and egg. These bakery products are high in calories, fat and carbohydrates and poor in fiber and protein.

Rice bran is derived from the outer layer of the rice grain which is composed of an aleurone layer of the rice kernel with some proportion of the endosperm and germ, accounting for approximately $10 \%$ of the weight of the rice grain (Justo et al., 2013 and Rondanelli et al., 2011). Rice bran contains 25 to $30 \%$ fiber and its soluble fibers can affect blood cholesterol level when combined with biliary acid. The stabilized rice bran, unlike wheat bran as well as other fibers, has sweet and palatable taste (Bagheri and Seyedein, 2011). Different milling degrees of rice bran stabilized by extrusion process are very rich in phosphorus, potassium and contain suitable amounts of all essential and nonessential amino acids. The highest values of protein, ash, phenolic compounds and dietary fiber, high amounts of essential amino acids and all elements are present in the $1^{\text {st }}$ fraction compared with those of other rice bran fractions (Abd ElGaleel and El-Bana, 2012). Rice bran is composed of lipophilic antioxidants (tocopherols, tocotrienols and $\gamma$-oryzanol) and phenolics (Min et al., 2011). Moreover, rice bran is a very rich source of oils, wax, trace elements, antioxidants, phytosterols, and phytochemicals. It contains high energy ( $373 \mathrm{cal} / 1$ cup or $118 \mathrm{~g}$ ), high protein, high fiber, with low sodium, and low sugar. It is a good source of manganese, magnesium, potassium, calcium, phosphorus, and vitamins (B1, B2, B6 and pantothenic acid). Rice bran in its crude or stabilized form is a potential dietary source which can be used as a nutritional supplement to prevent nutrient deficiencies in malnourished children (Rabbani and Ali, 2009). These substances provide 
protection against chronic diseases of the cardiovascular system and help to quench the free radicals and anti-cancer effects (Abdul Hamid et al., 2007 and Renuka and Arumughan, 2007). Rice bran inhibits the growth of human colon cancer cells. Some phenolic compounds have been reported to inhibit the growth of human breast and colon cancer cells (Verschoyle et al., 2007.)

Some bakery products are good source of dietary fiber and may serve as low caloric diet. High fiber content in food products helps to overcome health problems such as high cholesterol, hypertension, diabetes, colon cancer and intestinal disorders (Pasha et al., 2008). The addition of rice bran to wheat flour further increases the protein, lysine and dietary fiber contents in bread and cookies. The nutritional and functional properties of rice bran are suitable for baked products, namely cookies, muffins, breads, crackers, pastries and pancakes. Defatted rice bran can be used to substitute wheat flour up to $10-20 \%$ for making cookies without adversely affecting the quality (Sharif et al., 2009).

Wheat flour cookies prepared from wheat, corn, rice and psyllium with addition of some fiber sources were sensory evaluated by Pasha $e t$ al. (2008). Cookies containing wheat bran $(20 \%)$, corn bran $(20 \%)$, rice bran $(20 \%)$ or psyllium husk (10\%) were highly accepted. Meanwhile wheat, soybean and rice bran flour blends were used for the formulation of proteinrich biscuits, and no significant difference was observed between the composite sample (wheat $70 \%$, soybean $20 \%$ and rice bran $10 \%$ ) and control in general preference of sensory ratings. Proximate compositions of the best-rated composite flour biscuit were protein $(16.28 \%)$, fiber $(1.90 \%)$, fat $(12.13 \%)$ and moisture (4.37\%) (Bunde et al., 2010). Biscuit supplemented with defatted rice bran $(5,10$ and $15 \%)$ was considered more nutritive compared with control (wheat flour biscuit). It has higher contents of protein, ash and crude fiber. Furthermore, it has higher levels of phosphorus, potassium, zinc and manganese. The supplementation with defatted rice bran instead of wheat flour up to $10 \%$ was more suitable, while supplementation with $15 \%$ was just acceptable for the sensory evaluation of biscuits (Abd El-Galeel and El-Bana, 2012). Another study was conducted on wheat flour biscuits supplemented with both of soya and rice bran at $10 \%, 15 \%, 20 \%, 25 \%$ levels of each to improve the quality of food products and functional properties. Sensory evaluation of prepared biscuit decreases with increasing the level of substitution. Overall acceptability score for biscuit with $15 \%$ soy flour ${ }^{+} 15 \%$ rice bran showed the highest rating compared to other treatments (Mishra and Chandra, 2012). In a case study on cake and pan bread prepared with stabilized rice bran at 10, 20 and $30 \%$ replacement levels, the results indicated that there was no significant difference observed for sensorial evaluated and control in cake replaced with up to $30 \%$. While, pan bread with $20 \%$ replacement level had no significant differences in most characteristics except for texture and flavor (Abd El-kader and Hendawy, 2013).

This study aimed to use rich source of nutrients to prepare Kahk El-Eid and Petit-four for Egyptians Muslims.

\section{MATEREIALS AND METHODS \\ 2.1. MATERIALS}

2.1.1. Rice variety (Sakha10) was obtained from Meet El Deba experimental farm of rice Mechanization Center (R.M.C) and dried to have moisture content of $14 \%$, then milled.

Fresh rice bran stabilized in (R.M.C) in one pitch experimental heating unit immediately at $110^{\circ} \mathrm{C}$ for 20 min exposure time according to the method (Abd El-kader and Hendawy, 2013).

The obtained stabilized rice bran was packaged in polyethylene bags in (R.M.C) then kept to use in bakery products.

2.1.2. Flour for confectionary bakery products, Butter, milk, egg, yeast, powder sugar, salt and vanillin were obtained from local markets.

\subsection{METHODS}

2.2.1. Kahk El-Eid and petit-four prepared according to the methods described by Saba (2005). Both Kahk El-Eid and Petit-four were prepared from wheat flour (72\% extraction rate ) and stabilized rice bran (SRB) at replacement levels of 0,10, 20 and $30 \%$.

The formula of Kahk El-Eid and Petit-four are shown in Table (1).

\subsubsection{Kahk El-Eid preparation}

Scaled fat was added to wheat flour and stirred by wooden spoon until the mixture became warm. Yeast was dissolved in little warm water then mixed well with the previous mixture. Salt was dissolved in milk and then added to the obtained hard dough. The dough was divided to small parts, round and put in decoration pan to form the crust shape, then placed in greased baking tray, let to ferment and baked in preheated oven at $190^{\circ} \mathrm{C}$ for $20 \mathrm{~min}$. 
Table (1): The formula of Kahk El- Eid and Petit-four.

\begin{tabular}{|c|c|c|}
\hline Ingredients, $\mathbf{g}$ & Petit-four & Kahk El -Eid \\
\hline Wheat flour* & 150 & 200 \\
\hline Butter & 100 & 100 \\
\hline Egg & 40 & - \\
\hline Yeast & - & 5 \\
\hline Salt & - & 0.2 \\
\hline Milk, ml & - & 50 \\
\hline Powder Sugar & 50 & - \\
\hline Vanillin & 0.3 & - \\
\hline Sesame & - & 20 \\
\hline Sodiumbicarbonate & - & 2 \\
\hline
\end{tabular}

\subsubsection{Petit-four preparation}

Fat was creamed at medium speed to light color, then powdered sugar was added gradually until fluffy appearance is formed. Eggs were added one after the other and finally vanillin. Wheat flour was added at three patches and mixed gently to form smooth dough. The dough was left for $20 \mathrm{~min}$ to rest, then formed to flower shape with machine. The Petit-four was baked in preheated oven at $180^{\circ} \mathrm{C}$ to reach golden color.

\subsubsection{Rice bran preparation}

Stabilized rice bran (SRB) was fractionated using sieving shaker model D-5657 Haan, Germany to obtain fractions of particle size higher than 500, 400, 355, $200,160 \mu \mathrm{m}$ and lower than $160 \mu \mathrm{m}$. All the fractions with particle size below $400 \mu \mathrm{m}$ were collected together and used for replacing wheat flour at different levels for preparing Kahk El-Eid and Petit-four.

\subsubsection{Analytical methods}

Moisture, crude protein, crude fiber, ether extract (fat), and ash contents of wheat flour and stabilized rice bran fractions were determined according to the methods described in A.O.A.C (2005). The total carbohydrate was calculated as the following equation.

carbohydrate $\%=100-[$ fat $\%+$ crudeprotein $\%+$ crwdefiber $\%+$ ash content $\%]$

Fractionated stabilized rice bran minerals $(\mathrm{Mg}, \mathrm{Na}, \mathrm{Zn}, \mathrm{Mn}, \mathrm{Fe}, \mathrm{Ca}$ and $\mathrm{K}$ ) were determined by using Atomic Absorption Spectrophotometer (Perkin Elmer Model 4100ZI) according to A.O.A.C (2007) No. 4070 , using the dry ashing method for samples preparation.

\subsubsection{Measurement of volume and density}

The most commonly encountered method for measuring product volume is using seed displacement. The volume of seed displaced is equal to the volume of the product. The more seed that is displaced the larger the product volume. After volume data are obtained, it is common practice to consider product density. This is simply described as the mass of the product divided by its volume, $\mathrm{d}=\mathrm{m} / \mathrm{v}$. An alternative form of expressing such information is as specific volume (SV) which is simply the reciprocal of density, that is sample volume divided by sample mass, $\mathrm{SV}=\mathrm{v} / \mathrm{m}$. Both density and SV terms are encountered in discussions of baked-product quality, the lower the product density, the higher its specific volume and vice versa (Cauvain and Young,2006).

\subsubsection{Sensory evaluation of the products}

The obtained Kahk El-Eid and Petit-four products were sensory evaluated according to the method described by Bunde et al.( 2010). Some parameters were added to the method to cover the sensory characteristics of Kahk El-Eid and Petit-four. The evaluated parameters were general appearance, crust color, crumb color, softening, mouth feel, crispness, odor and taste. The score sheet is presented in Table (2).

Table (2): Score sheet for sensory evaluation of Kahk El-Eid and Petit-four.

\begin{tabular}{|l|c|c|}
\hline \multicolumn{1}{|c|}{ Properties } & Kahk El- Eid & Petit-four \\
\hline $\begin{array}{l}\text { General } \\
\text { appearance }\end{array}$ & 10 & 20 \\
\hline Crust color & 10 & 20 \\
\hline Crumb color & 10 & - \\
\hline Softening & 15 & 10 \\
\hline Mouthfeel & 15 & - \\
\hline crispness & - & 10 \\
\hline Odor & 20 & 20 \\
\hline Taste & 20 & 20 \\
\hline
\end{tabular}

\subsubsection{Hardness}

Hardness was the maximum load, expressed in $\mathrm{kg}$, applied to the samples during the first compression. Hardness was the force required to bite completely through the sample when placed between molars, (Meulleneti et al.,1998).

\subsubsection{Statistical analysis}

The obtained data were exposed to analysis of variance. Duncan's multiple range tests at $P \leq$ 0.05 level was used to compare between means. The analysis was carried out using the PRO ANOVA procedure of Statistical Analysis System (SAS, 1996).

\section{RESULTS AND DISCUSSION}

\subsection{Rice bran fractionation}

Table (3) illustrates the percentages of ractions of stabilized rice bran. The percentage 
accumulated under sieves $400 \mu \mathrm{m}$ was $66.48 \%$. The high fraction percentage of stabilized rice bran (33.38\%) was found above sieve of 200 $\mu \mathrm{m}$. Quilez et al. (2013) mentioned that particles size of rice bran extruded and steam stabilized were 31.7 and $20.9 \%$ in size of $0.5 \mathrm{~mm}, 51.7$ and $65.6 \%$ in size of 0.5 to $0.3 \mathrm{~mm}, 12.5$ and $9.7 \%$ in size of $0.3-0.25 \mathrm{~mm}, 3.7$ to $3.6 \%$ in size of 0.25 to $0.20 \mathrm{~mm}$ and 0.4 to $0.2 \%$ in size of 0.2 to $0.125 \mathrm{~mm}$.

Table (3): Sieving shaker percentages of stabilized rice bran.

\begin{tabular}{|c|c|c|}
\hline Diameter of holes & Weight $(\mathrm{g})$ & $\%$ \\
\hline $500 \mu \mathrm{m}$ & $\mathbf{1 5 0 . 7 8}$ & $\mathbf{2 5 . 1 3}$ \\
\hline $400 \mu \mathrm{m}$ & 50.34 & 8.39 \\
\hline $355 \mu \mathrm{m}$ & $\mathbf{6 8 . 8 2}$ & 11.47 \\
\hline $200 \mu \mathrm{m}$ & 200.28 & 33.38 \\
\hline $160 \mu \mathrm{m}$ & 129.78 & 21.63 \\
$>160 \mu \mathrm{m}$ & trace & - \\
\hline
\end{tabular}

\subsection{Chemical composition of wheat flour} $72 \%$, whole stabilized rice bran and its fractions (on dry weight basis)

The chemical composition of wheat flour and stabilized rice bran fractions are presented in Table (4). The chemical analysis showed that the stabilized rice bran contained high protein, fat, ash and fiber than wheat flour. Arafa et al. (2014) showed that the chemical components of wheat flour and stabilized defatted rice bran were protein $(11.15,13.83)$, ether extract $(1.38,1.41)$, ash $(0.56,8.64)$ and fiber $(0.71$, 8.36).

The data of stabilized rice bran showed that the fraction of $400 \mu \mathrm{m}$ had high protein content, while high fiber was found in the fraction of 355 $\mu \mathrm{m}$ and high ash was found in the fraction of $200 \mu \mathrm{m}$. On the other hand, the coarse sieving fraction of $500 \mu \mathrm{m}$ was higher in fat and lower in fiber content. The fine fractions (355 and $400 \mu \mathrm{m})$ were high in fiber and protein content, respectively, compared to whole rice bran. The chemical constituents of rice bran accumulated under sieve 400 were fat $19.92 \%$, protein $11.48 \%$, ash $8.08 \%$ and fiber content $5.67 \%$. Numerous studies conducted on rice bran showed that moisture, crude protein, and crude fat were found to be $18,18.17 \%, 12.60$, $13.25 \%$ and $16.67,16.93 \%$, for acid stabilized rice bran and heat-stabilized rice bran respectively, (Younas et al., 2011). Esa et al. (2013) mentioned that, the protein, fat, fiber and ash contents in rice bran ranged between 10.6 to $16.9 \%, 5.1$ to $19.7 \%, 7.0$ to $18.9 \%$ and 8.8 to $28.8 \%$, respectively.

3.3. Mineral content of wheat flour, whole stabilized rice bran and its fractions

Results in Table (5) indicated that rice bran was a good source for minerals. The data showed that $\mathrm{Mg}, \mathrm{Zn}, \mathrm{Mn}, \mathrm{Fe}, \mathrm{Ca}$, and $\mathrm{K}$ contents in stabilized rice bran were higher than those in wheat flour. Fraction of $500 \mu \mathrm{m}$ had higher content in $\mathrm{Zn}(17.02 \mathrm{mg} / 100 \mathrm{~g})$. Meanwhile, fraction of $355 \mu \mathrm{m}$ had higher content of $\mathrm{Na}$ $(354.67 \mathrm{mg} / 100 \mathrm{~g})$ and $\mathrm{Mn}(58.82 \mathrm{mg} / 100 \mathrm{~g})$. High values of $\mathrm{Ca}, \mathrm{K}$ and $\mathrm{Mg}$ were found in fraction of $160 \mu \mathrm{m}$, being $8.84 \mathrm{mg} / 100 \mathrm{~g}, 3.18 \%$ and $1.59 \%$, respectively. Iron content was recorded to be $51.3 \mathrm{mg} / 100 \mathrm{~g}$ in fraction of 200 $\mu \mathrm{m}$. Moderate values were detected in $\mathrm{Zn}, \mathrm{Mn}$, $\mathrm{Fe}$ and $\mathrm{K}$ in rice bran accumulated under sieve $400 \mu \mathrm{m}$, but these values were higher than those

Table (4): Chemical composition of wheat flour $72 \%$, whole stabilized rice bran and its fractions (as dry weight basis).

\begin{tabular}{|c|c|c|c|c|c|c|}
\hline Samples & $\begin{array}{c}\text { Moisture } \\
\%\end{array}$ & $\begin{array}{c}\text { Fat } \\
\%\end{array}$ & $\begin{array}{c}\text { Protein } \\
\%\end{array}$ & $\begin{array}{l}\text { Ash } \\
\%\end{array}$ & $\begin{array}{c}\text { Fiber } \\
\%\end{array}$ & $\begin{array}{l}\text { Carbohyd- } \\
\text { rates, \% }\end{array}$ \\
\hline Wheat flour $72 \%$ & 12.76 & 1.55 & 11.71 & 0.64 & 0.49 & 85.61 \\
\hline Whole meal R.B & 7.98 & 19.87 & 13.34 & 7.55 & 5.28 & 53.96 \\
\hline \multicolumn{7}{|c|}{ Rice bran fractions } \\
\hline $500 \mu \mathrm{m}$ & 7.86 & 21.15 & 13.96 & 6.97 & 2.71 & 55.21 \\
\hline $400 \mu \mathrm{m}$ & 7.07 & 20.76 & 15.84 & 6.69 & 5.75 & 50.96 \\
\hline $355 \mu \mathrm{m}$ & 7.34 & 20.85 & 11.72 & 8.03 & 8.91 & 50.49 \\
\hline $200 \mu \mathrm{m}$ & 7.11 & 20.51 & 11.38 & 8.24 & 5.75 & 54.12 \\
\hline $\begin{array}{c}160 \mu \mathrm{m} \\
\text { Under } \\
\text { seive400 } \mu \mathrm{m}\end{array}$ & 7.48 & $\begin{array}{l}18.56 \\
19.92 \\
\end{array}$ & $\begin{array}{l}11.51 \\
11.48 \\
\end{array}$ & $\begin{array}{r}7.84 \\
8.08 \\
\end{array}$ & $\begin{array}{l}3.80 \\
5.67 \\
\end{array}$ & $\begin{array}{l}58.29 \\
54.85 \\
\end{array}$ \\
\hline
\end{tabular}


Table (5): Mineral content in wheat flour, whole stabilized rice bran and its fractions.

\begin{tabular}{|c|c|c|c|c|c|c|c|}
\hline Samples & $\begin{array}{c}\mathrm{Mg} \\
\% \\
\end{array}$ & $\begin{array}{c}\mathrm{Na} \\
\mathrm{mg} / 100 \mathrm{~g}\end{array}$ & $\begin{array}{c}\mathrm{Zn} \\
\mathrm{mg} / 100 \mathrm{~g}\end{array}$ & $\begin{array}{c}\text { Mn } \\
\mathrm{mg} / 100 \mathrm{~g}\end{array}$ & $\begin{array}{c}\text { Fe } \\
\mathrm{mg} / 100 \mathrm{~g}\end{array}$ & $\begin{array}{c}\mathrm{Ca} \\
\mathrm{mg} / 100 \mathrm{~g}\end{array}$ & $\begin{array}{l}\mathbf{K} \\
\%\end{array}$ \\
\hline Wheat flour $\mathbf{7 2 \%}$ & 0.06 & 119.17 & 1.89 & 0.45 & 5.20 & 1.9 & 0.23 \\
\hline whole meal R.B & 1.15 & 116.19 & 14.42 & 17.20 & 32.33 & 3.64 & 0.68 \\
\hline \multicolumn{8}{|c|}{ Rice bran fractions } \\
\hline $500 \mu \mathrm{m}$ & 1.41 & 117.83 & 17.02 & 20.24 & 35.76 & 3.46 & 1.16 \\
\hline $400 \mu \mathrm{m}$ & 1.18 & 124.79 & 12.99 & 18.85 & 31.27 & 3.82 & 1.25 \\
\hline $355 \mu \mathrm{m}$ & 1.19 & 354.67 & 12.38 & 58.82 & 34.98 & 6.28 & 0.93 \\
\hline $200 \mu \mathrm{m}$ & 1.26 & 109.63 & 16.34 & 21.20 & 51.30 & 4.06 & 1.16 \\
\hline $160 \mu \mathrm{m}$ Under sieve & 1.59 & 114.27 & 16.13 & 24.45 & 34.46 & 8.84 & 3.14 \\
\hline $400 \mu \mathrm{m}$ & 1.36 & 153.09 & 15.59 & 28.75 & 43.00 & 6.03 & 1.76 \\
\hline
\end{tabular}

determined in wheat flour. Younas et al.(2011) mentioned that heat stabilized rice bran contained 63.24 ppm Fe, 16.53 ppm Mn, 24.44 ppm Zn, 294.88 ppm Ca and 270 ppm Mg. The results reported by Rosniyana et al. (2007) showed that minerals contents in rice bran at $4 \%$ milling degree stabilized by autoclaving, were $\mathrm{Fe}$ 14, K 1170, Ca 54, Mg 823 and $\mathrm{Na} 24$ $\mathrm{mg} / 100 \mathrm{~g}$.

3.4. The chemical composition of kahk El-Eid and Petit-four prepared from wheat flour with SRB at different replacement levels

The chemical composition of kahk El-Eid and Petit-four prepared from wheat flour replaced by SRB at levels of 0,10,20, and 30\% are presented in Tables 6 and 7 .

\subsubsection{Chemical composition of kahk El-Eid prepared from wheat flour and stabilized rice bran at different replacement levels}

Table (6) reveal that a gradual increase in protein, fat, ash and fiber content was observed with increasing the replacement levels by rice bran.

Fat was the highest component content of $29.13 \%$ in control, while ranged between 30.01 and $31.88 \%$ in Kahk El-Eid prepared with stabilized rice bran; the percent of increase was $9.44 \%$ between control and $30 \%$ replacement. There was a noticeable increase in fiber content in Kahk- El-Eid samples as replacement levels by SRB increased. The percentage of fiber increment was $191.49 \%$ in the higher replacement level (30\%). The ash content was $1.05 \%$ in control and percentage of increase was $105.71 \%$ in $30 \%$ replacement level by stabilized rice bran compared with control. There is no visible increase in protein content in Kahk- El Eid prepared with stabilized rice bran compared to control. In regards with minerals content in
$100 \mathrm{~g}$ of Kahk El-Eid samples prepared with replacement level $30 \%$ by stabilized rice bran, $\mathrm{Zn} \mathrm{Fe}, \mathrm{Mn}$ and $\mathrm{K}$ contents were found to cover $30,50.83,216.5$ and $8.49 \%$ of daily requirement for adults (RDI, 2011).

3.4.2. Chemical composition of petit- four prepared from wheat flour with replacement by SRB at different levels

Table (7) demonstrate a clear increase in fat, ash and fiber content in petit- four samples compared with control. There is a little increase in protein content of petit-four samples prepared with 10,20 and $30 \%$ stabilized rice bran which was $3.48 \%$ in high replacement percentage. The increment of fat, ash and fiber was 8.80, 173.08 and $400 \%$, for 10,20 and $30 \%$ SRB replacement levels respectively. The minerals content in petit-four prepared from wheat flour with stabilized rice bran increase by increasing of the replacement of rice bran. Obvious increases were observed in $\mathrm{Zn}, \mathrm{Mn}$ and $\mathrm{Fe}$ content in Petit-four samples containing SRB than control. One hundred gram of Petit four prepared with $30 \%$ stabilized rice bran contain Zn cover $29.73 \%$, Mn cover 183.04, Fe cover $40.50 \%$ and $\mathrm{K}$ cover 7.84 of daily requirement for adults.

From the data presented in Tables (6 and 7) it can be concluded that there is a regular increase in chemical composition of Kahk El-Eid and petit-four samples prepared from wheat flour replaced by 10, 20 and $30 \%$ stabilized rice bran compared to control one. The increase in fat content was higher in Kahk El-Eid $(9.44 \%)$ than in petit-four samples $(8.80 \%)$, while the increase was lower in ash (105.71 and $173.08 \%$ ), fiber (191.49 and 400.0\%) and protein content (1.47 and $3.48 \%$ ) for Kahk El-Eid and petit four samples, respectively. The mineral content in $100 \mathrm{~g}$ of Kahk El-Eid and petit-four cover the 
Table (6): Chemical composition of kahk El-Eid prepared from wheat flour and stabilized rice bran at different replacement levels.(on dry weight basis).

\begin{tabular}{|c|c|c|c|c|c|}
\hline Component & $\begin{array}{c}\text { Control } \\
(\%)\end{array}$ & $\begin{array}{c}10 \% \text { SRB } \\
(\%)\end{array}$ & $\begin{array}{c}20 \% \text { SRB } \\
(\%)\end{array}$ & $\begin{array}{c}30 \% \text { SRB } \\
(\%)\end{array}$ & $\begin{array}{c}\text { RDI, 2011 } \\
(\text { adults })\end{array}$ \\
\hline Protein & 9.51 & 9.39 & 9.56 & 9.65 & 56 g/d \\
\hline Fat & 29.13 & 30.01 & 31.05 & 31.88 & ND \\
\hline Ash & 1.05 & 1.42 & 1.70 & 2.16 & - \\
\hline Fiber & 0.47 & 0.78 & 1.02 & 1.37 & 38 g/d \\
\hline Carbohydrate & 59.84 & 58.40 & 56.67 & 54.94 & 130 g/d \\
\hline \multicolumn{7}{|c|}{ Minerals(mg/100g) } \\
\hline Mg & 17.36 & 112.83 & 179.49 & 246.16 & 420 mg/d \\
\hline Na & 74.77 & 77.79 & 80.82 & 83.84 & 1.5 g/d \\
\hline Zn & 1.29 & 1.96 & 2.63 & 3.30 & 11 mg/d \\
\hline Mn & 0.24 & 1.86 & 3.48 & 4.98 & $2.3 \mathrm{mg} / \mathbf{d}$ \\
\hline Fe & 3.89 & 5.65 & 7.50 & 9.15 & 18 mg/d \\
\hline Ca & 78.58 & 78.78 & 78.98 & 78.19 & $1.3 \mathrm{mg} / \mathbf{d}$ \\
\hline K & 66.98 & 253.11 & 323.51 & 399.25 & 4.7 g/d \\
\hline
\end{tabular}

Table (7): Chemical composition of petit-four prepared from wheat flour with stabilized rice bran at 10,20 and $30 \%$, replacement levels.

\begin{tabular}{|c|c|c|c|c|c|}
\hline Component & $\begin{array}{c}\text { Control } \\
(\%)\end{array}$ & $\begin{array}{c}\text { 10\% SRB } \\
(\%)\end{array}$ & $\begin{array}{c}20 \% \text { SRB } \\
(\%)\end{array}$ & $\begin{array}{c}\text { 30\% SRB } \\
(\%)\end{array}$ & $\begin{array}{c}\text { RDI } \\
\text { ( adults) }\end{array}$ \\
\hline Protein & 6.60 & 6.68 & 6.76 & 6.83 & $56 \mathrm{~g} / \mathrm{d}$ \\
\hline Fat & 26.81 & 26.04 & 28.38 & 29.17 & ND \\
\hline Ash & 0.52 & 0.83 & 1.11 & 1.42 & - \\
\hline Fiber & 0.19 & 0.44 & 0.69 & 0.95 & $38 \mathrm{~g} / \mathrm{d}$ \\
\hline Carbohydrate & 65.88 & 66.01 & 63.06 & 61.63 & $130 \mathrm{~g} / \mathrm{d}$ \\
\hline \multicolumn{6}{|c|}{ Minerals $(\mathbf{m g} / \mathbf{1 0 0 g})$} \\
\hline Mg & 6.29 & 86.93 & 143.23 & 199.54 & $420 \mathrm{mg} / \mathrm{d}$ \\
\hline $\mathbf{N a}$ & 86.07 & 88.62 & 91.71 & 93.73 & $1.5 \mathrm{~g} / \mathrm{d}$ \\
\hline$\overline{Z n}$ & 1.57 & 2.14 & 2.70 & 3.27 & $11 \mathrm{mg} / \mathrm{d}$ \\
\hline Mn & 0.20 & 1.57 & 2.94 & 4.21 & $2.3 \mathrm{mg} / \mathrm{d}$ \\
\hline $\mathbf{F e}$ & 2.86 & 4.34 & 5.91 & 7.29 & $18 \mathrm{mg} / \mathrm{d}$ \\
\hline $\mathbf{C a}$ & 16.49 & 16.66 & 16.83 & 17.01 & $1.3 \mathrm{mg} / \mathrm{d}$ \\
\hline $\mathbf{K}$ & 49.14 & 206.35 & 268.81 & 368.56 & $4.7 \mathrm{~g} / \mathrm{d}$ \\
\hline
\end{tabular}

daily requirement for adults in $\mathrm{Mn}$, and Ca.Microwave stabilized defatted rice bran was added to wheat flour at replacement levels of 10 , $20,30,40$ and $50 \%$ to prepare fiber and mineral enriched cookies and to improve dietary fiber content and mineral profile of the cookies (Sharif et al., 2009).

\subsubsection{Sensory evaluation of Kahk El-Eid} prepared from wheat flour replaced by Stabilized rice bran at different levels

Sensory evaluation values of Kahk El-Eid prepared from wheat flour replaced by stabilized rice bran are presented in Table (8). The obtained results indicated that samples of Kahk
El-Eid contained10\% SRB were significantly different from control for general appearances, crust color, crumb color and mouth feel, while softening, taste and odor were found to be not significantly different from control. Concerning $20 \%$ SRB level, the samples were significantly different from control for all the evaluated characteristics except odor. At 30\% SRB replacement level, all the evaluated characteristics of the samples were significantly different from control. The obtained data agreed with Younas et al. (2011) who mentioned that addition of heat-stabilized rice bran to wheat flour cookies got the highest scores for color, 
Table(8): Sensory evaluation of Kahk-El Eid prepared from wheat flour with stabilized rice bran at 10,20 and $30 \%$, replacement levels.

\begin{tabular}{|c|c|c|c|c|c|c|c|}
\hline Samples & $\begin{array}{c}\text { General } \\
\text { appearance } \\
(10)\end{array}$ & $\begin{array}{c}\text { Crust } \\
\text { color } \\
(10)\end{array}$ & $\begin{array}{c}\text { Crumb } \\
\text { color }(10)\end{array}$ & $\begin{array}{c}\text { Softening } \\
\text { (15) }\end{array}$ & $\begin{array}{l}\text { Mouth } \\
\text { feel (15) }\end{array}$ & $\begin{array}{c}\text { Taste } \\
(20)\end{array}$ & $\begin{array}{l}\text { Odor } \\
\text { ( 20) }\end{array}$ \\
\hline Control & $9.8 \mathrm{a} \pm 0.4$ & $9.8 \mathrm{a} \pm 0.4$ & $9.8 \mathrm{a} \pm 0.4$ & $14.7 \mathrm{a} \pm 0.4$ & $14.7 \mathrm{a} \pm 0.4$ & $19.7 \mathrm{a} \pm 0.6$ & $19.8 \mathrm{a} \pm 0.4$ \\
\hline $10 \%$ SRB & $9.0 \mathrm{~b} \pm 0.4$ & $9.0 \mathrm{~b} \pm 0.4$ & $8.9 b \pm 0.5$ & 13.7 a \pm 0.8 & $13.6 \mathrm{~b} \pm 0.8$ & $18.2 \mathrm{ab} \pm 1.6$ & $19.3 \mathrm{a} \pm 0.8$ \\
\hline $20 \%$ SRB & $8.3 c \pm 0.6$ & $8.3 \mathrm{c} \pm 0.4$ & $7.7 \mathrm{c} \pm 1.6$ & $12.2 \mathrm{~b} \pm 1.6$ & $12.8 b \pm 0.9$ & $16.9 \mathrm{~b} \pm 1.9$ & $18.5 \mathrm{ab} \pm 1.5$ \\
\hline $30 \%$ SRB & $7.1 d \pm 0.7$ & $7.1 \mathrm{~d} \pm 0.7$ & $6.9 \mathrm{~d} \pm 0.9$ & $10.9 \mathrm{~b} \pm 2.1$ & $11.5 c \pm 1.6$ & $15.0 \mathrm{c} \pm 2.6$ & $17.1 b \pm 2.7$ \\
\hline
\end{tabular}

*Data are presented as means $\pm \mathrm{SD}(n=10)$ In a column, means having the same letters are not significantly different at $5 \%$ level.

taste, flavor, texture and overall acceptability and the color of cookies decreased significantly with the increase in the level of rice bran. Sudha et al.(2007) reported that progressive increase in supplementation level of rice bran produced progressively darker cookies. Sharma and Chauhan (2002) reported that flavor response decreased with the increase in the level of bran in the cookies up to 20 percent replacement of flour by wheat bran. Defatted rice bran can be used up to $10-20 \%$ replacement levels in wheat flour to prepare rice bran supplemented cookies without adversely affecting quality attributes (Sharif et al., 2009).

3.4.4. Sensory evaluation of Petit-four prepared from wheat flour replaced by Stabilized rice bran at different levels

From the results in Table (9) it can be noticed that sensory evaluation values of Petit-four samples contained 10\% SRB were not significantly different from control for all parameters. While, Petit-four samples containing $20 \%$ SRB level were found to be significantly different in all parameters (general appearance, color, crispness, softness and taste) except for odor. Concerning Petit-four samples of $30 \%$ SRB replacement level, all parameters were significantly different from control. Sudha et al. (2007) mentioned that rice bran incorporation in biscuit ingredients increased the darkness and reduced the surface smoothness. Above 30\% incorporation of rice bran in the biscuits resulted in dark crumb color and very hard texture. Taste of the biscuits was affected at $20 \%$ level. The mouth feel became dry. In a study by Quilez et al. (2013) the sensory evaluation values of bread were found to decrease with increasing the level of rice bran from 3 to $9 \%$ in bread. In the same time the bread with $9 \%$ rice bran having off flavor pointed in the sensory evaluation.

3.4.5. Specific weight and specific volume of Kahk El-Eid and Petit four prepared from wheat flour replaced by stabilized rice bran at different levels

Specific volume and specific weight values for both of Kahk El-Eid and petit -four prepared from wheat flour replaced by SRB at three levels $(10,20$ and $30 \%)$ are presented in Table (10). The results indicated that specific volume of Kahk El-Eid slightly decreased with increasing the rice bran replacement levels, while specific volume of Petit-four samples increased. These results mean that the proportion of volume to weight decreased as a result of the increase of weight of kahk El-Eid. The increase of specific weight in petit- four may be related to the decrease of the weight proportion to volume. Majzoobi et al. (2013) mentioned that using a higher quantity of bran (20\%) with larger particle sizes $(210 \mathrm{~mm})$ increased cake density and weight of the cakes while decreased the cake volume.

Table (9): Sensory evaluation of Petit-four prepared from wheat flour with stabilized rice bran at 10,20 and $30 \%$, replacement levels.

\begin{tabular}{|c|c|c|c|c|c|c|}
\hline Samples & $\begin{array}{c}\text { General } \\
\text { appearance (20) }\end{array}$ & $\begin{array}{l}\text { Color } \\
(20)\end{array}$ & $\begin{array}{c}\text { Crispness } \\
\text { (10) }\end{array}$ & $\begin{array}{l}\text { Softness } \\
(10)\end{array}$ & $\begin{array}{l}\text { Odor } \\
(20)\end{array}$ & $\begin{array}{l}\text { Taste } \\
(\mathbf{2 0})\end{array}$ \\
\hline Control & 18.5 a \pm 0.9 & $18.7 \mathrm{a} \pm 0.6$ & $8.3 \mathrm{a} \pm 0.9$ & $8.8 a \pm 0.6$ & $18.8 \mathrm{a} \pm 0.7$ & $18.8 \mathrm{a} \pm 0.6$ \\
\hline $10 \%$ SRB & 17.8 ab \pm 0.6 & $18.1 \mathrm{ab} \pm 1.1$ & $8.1 \mathrm{ab} \pm 0.6$ & $8.2 \mathrm{a} \pm 0.6$ & 18.6 a \pm 0.9 & $18.5 \mathrm{ab} \pm 1.6$ \\
\hline $20 \%$ SRB & $17.1 \mathrm{~b} \pm 1.6$ & $17.2 \mathrm{~b} \pm 1.6$ & $7.4 \mathrm{~b} \pm 0.8$ & $7.2 \mathrm{~b} \pm 0.4$ & 18.2 a \pm 1.3 & $17.3 \mathrm{bc} \pm 1.3$ \\
\hline $30 \%$ SRB & $15.3 \mathrm{c} \pm 1.4$ & $15.0 \mathrm{c} \pm 2.1$ & $6.4 c \pm 0.8$ & $6.2 c \pm 0.9$ & $16.5 \mathrm{~b} \pm 2.9$ & $16.2 \mathrm{c} \pm 2.0$ \\
\hline
\end{tabular}

*Data are presented as means $\pm \mathrm{SD}(n=10)$. In a column, means having the same letters are not significantly different at $5 \%$ level. 
Table (10): Specific weight and specific volume of Kahk El-Eid and Petit-four prepared from wheat flour with stabilized rice bran at 10,20 and $30 \%$, replacement levels.

\begin{tabular}{|c|c|c|c|c|}
\hline Samples & $\begin{array}{c}\text { Specific } \\
\text { volume } \mathrm{cm}^{3} / \mathrm{g}\end{array}$ & $\begin{array}{c}\text { Specific weight } \\
\mathrm{g} / \mathrm{cm}^{\mathbf{3}}\end{array}$ & $\begin{array}{c}\text { Specific volume } \\
\mathrm{cm}^{3} / \mathrm{g}\end{array}$ & $\begin{array}{c}\text { Specific weight } \\
\mathrm{g} / \mathrm{cm}^{3}\end{array}$ \\
\hline & \multicolumn{2}{|c|}{ Kahk El-Eid } & \multicolumn{2}{c|}{ Petit-four } \\
\hline Control & 1.83 & $\mathbf{0 . 6 6}$ & 1.21 & 0.83 \\
\hline $10 \%$ SRB & 1.75 & 0.63 & 1.22 & 0.82 \\
\hline $20 \%$ SRB & 1.70 & 0.61 & 1.38 & 0.73 \\
\hline $30 \%$ SRB & 1.66 & 0.60 & 1.69 & 0.59 \\
\hline
\end{tabular}

$\mathrm{SRB}=$ Stabilized rice bran

\subsubsection{Hardness $(\mathrm{N})$ of Kahk El-Eid and Petit- four prepared from wheat flour replaced by stabilized rice bran at different levels}

The hardness values of Kahk El-Eid and Petitfour are presented in Table (11). The data revealed that hardness $(\mathrm{N})$ of Kahk El-Eid increased by increasing the replacement levels of stabilized rice bran. The highest increase was found in Kahk El-Eid with $20 \%$ replacement level of stabilized rice bran compared with $10 \%$ and the increase in hardness was $9.7 \mathrm{~N}$. Meanwhile, the increment was $2.45 \mathrm{~N}$ and 14.62 $\mathrm{N}$ for $10 \%$ and $30 \%$ replacement levels by stabilized rice bran compared with control samples. In regards with Petit-four, the hardness increased gradually by increasing the replacement levels of stabilized rice bran. These results were in agreement with Sudha et al. (2007) who mentioned that biscuits became harder as seen in the increasing breaking strength values especially at $30 \%$ and $40 \%$ levels of rice bran and were as high as 2.38 and $3.8 \mathrm{~kg}$, respectively. Majzoobi et al. (2013) reported that textural properties of the samples as determined instrumentally showed that maximum compressive force and the firmness increased, with increasing the contents of bran and its particle size.

Table (11): Hardness (N) of Kahk El-Eid and Petit-four prepared from wheat flour with stabilized rice bran at 10,20 and $30 \%$, replacement levels.

\begin{tabular}{|c|c|c|}
\hline Samples & Kahk El-Eid & Petit-four \\
\hline Control & 1.57 & 1.51 \\
\hline $10 \%$ SRB & 4.02 & 5.05 \\
\hline $20 \%$ SRB & 13.72 & 7.11 \\
\hline 30\% SRB & 16.19 & 12.11 \\
\hline
\end{tabular}

\section{REFERENCES}

Abd El-Galeel M. A. and El-Bana M. E. (2012). Effect of milling degree on chemical composition and nutritional value of stabilized rice bran. J. Agric. Res. Kafr El-Sheikh Univ. 38 (4): 550-567.

Abd El-kader Manal H. and Hendawy Y.T. (2013). Heat stabilization of rice bran and its application in some bakery products. Egypt. J. Agric. Res. 91(1): 67-84. Special Issue. Second international conference and Exhibition of Grain and its products.13-15.

Abdul-Hamid A., Raja Sulaiman R.R., Osman A. and Saari N. (2007). Preliminary study of the chemical composition of the rice milling fractions stabilized by microwave heating. J. of Food Composition and Analysis, 20 (7): 627-637.

A.O.A.C.(2005).Official methods of analysis of AOAC international (1 $17^{\text {th }} \mathrm{Ed}$.). Gaithersburg, Massachusetts, USA: AOAC International.

A.O.A.C.(2007). Official Methods of Analysis of the Association of Official Analytical Chemists. $18^{\text {th }}$ Ed Gaithersburg, Maryland, USA.

Arafa S.A., Nematalla Kh. M. and Khalil E.M (2014). Formulation and Evaluation of some high fiber products. Bull. Fac. Agric., Cairo Univ., 65:36-49.

Bagheri R. and Seyedein S. M. (2011).The effect of adding rice bran fibre on wheat dough performance and bread quality. World Appl. Sci., J. (Special Issue of Food and Environment). 14:121-125.

Bunde M.C., Osundahunsi F.O. and Akinoso R.(2010). Supplementation of biscuit using rice bran and soybean flour. Afri. J. of Food Agric., Nutri. and Develop., 10(9): 4047-4059.

Cauvain S. P. and Young L. S. (2006). Baked Products: Science, Technology and Practice. BakeTran, High Wycombe, Bucks, UK. Blackwell 9600 Gorsington road, oxford Ox 42DQ,UK Publishing. Pp 22-23. 
Esa N. M., Ling T. B. and Peng L. S.(2013). By-products of rice processing: An Overview of Health Benefits and Applications. Review article. J. Rice. Res. 1:1. http://dx.doi.org/10.4172/jrr.1000107.

Justo M.L., Rodriguez R.R., Claro C.M., Alvarez de Sotomayor M. and Parrado J. (2013). Water-soluble rice bran enzymatic extract attenuates dyslipidemia, hypertension and insulin resistance in obese Zucker rats. Eur. J. Nutr. 52: 789-797.

Majzoobi M., Sharif S., Imani B. and Farahnaky A. (2013).The effect of particle size and level of rice bran on the batter and sponge cake properties. J. Agric. Sci. Tech., 15: 1175-1184 .

Meulleneti J. F., Lyon B.G., Carpenter J. A. and Lyon C. E. (1998). Relationship between sensory and instrumental texture profile attributes. J. Sensory Studies, 13 : 77-93. Copyright $\mathrm{I} 998$ by Food \& Nutrition Press, Inc. Trumbull. Connecticut.

Min B., McClung A.M. and Chen M.H. (2011). Phytochemicals and antioxidant capacities in rice brans of different color. J. Food Sci. 76: C117-126.

Mishra N. and Chandra R. (2012). Development of functional biscuit from soy flour and rice bran. Inter. J. Agric. and Food Sci. 2(1): 14-20.

Pasha I., Parveen S., Rehman S. and Nawaz H. (2008). Baking quality of wheat flour cookies supplemented with fiber from different sources. Pak. J. Food Sci. 18 (14): $1-8$.

Quilez J., Zator M., Salas-salvado J. and Alvarez L. (2013). Different stabilization treatments of rice bran added to wheat flour determine different properties in partially baked wheat bread. Ital. J. Food Sci. 25 (2): 222-228.

Rabbani G.H. and Ali M. (2009). New ideas and concepts. Rice bran: A nutrient-dense mill-waste for human nutrition. Review Article. The ORION.32 : 3 www.oriongroup.net/medicaljournal

Renuka D. R. and Arumughan C. (2007). Phytochemical characterization of defatted rice bran and optimization of a process for their extraction and enrichment.
Bioresour. Tech. 98: 3037-3043.

RDI (2011). Food and Nutrition Board. Dietary references intakes, Estimated average requirements Institute of medicine, National Academies Copyright 2004 by Bational academy Sciences. www. map.edu.

Rondanelli M., Perna S., Monteferrario F. and Opizzi A. (2011). Update on the therapeutic qualities of the rice bran in the treatment of dyslipidemia and chemoprevention. Recenti. Prog. Med., 102: 310-313.

Rosniyana A., Hashifah M. A. and Shariffah Norin S.A.( 2007). The physico-chemical properties and nutritional composition of rice bran produced at different milling degrees of rice. J. Trop. Agric. and Food Sci. (JTAFS) 35 (1): 99-105.

Saba N. H. (2005). Culinary Science and Art Book. $9^{\text {th }}$ Edition, Dar Al Maaref. 1119 Cornish el Nile, Cairo Egypt. ISBN 97702-6788-0.

SAS Program (1996) . SAS/STAT User's guide release $6.12^{\text {ed }}$. Cary, NC, USA: SAS Inst. Inc.

Sharif M.K., Butt M.S., Anjum F.M. and Nawaz H. (2009). Preparation of fiber and mineral enriched defatted rice bran supplemented cookies. Pakistan J.Nutr., 8: 571-577.

Sharma H.R. and Chauhan G.S.(2002).Effect of stabilized rice bran-fenugreek blends on the quality of breads and cookies. J. Food Sci. Nutr., 39: 225-233.

Sudha M.L. Vetrimani R. and Leelavathi K. (2007). Influence of fibre from different cereals on the rheological characteristics of wheat flour dough and on biscuit quality. Food Chem. 100: 1365-1370.

Verschoyle R.D., Greaves P., Cai H., Edwards R.E., and Steward W.P. (2007). Evaluation of the cancer chemopreventive efficacy of rice bran in genetic mouse models of breast, prostate and intestinal carcinogenesis. Br. J. Cancer 96: 248-254.

Younas A., Bhatti M. S., Ahmed A. and Randhawa M. A. (2011). Effect of rice bran supplementation on cookie baking quality. Pak. J. Agri. Sci., 48 (2): 129-134. 
مخبوزات الاعياد باستخدام رجيع الارز المثبت حراريا

\section{منال حجاج عبد القادر}

قسم بحوث الخبز و العجائن ـ معهد بحوث تكنولوجيا الاغذية ـ مركز البحوث الزر اعية ـ الجيزة- مصر

\section{ملخص}

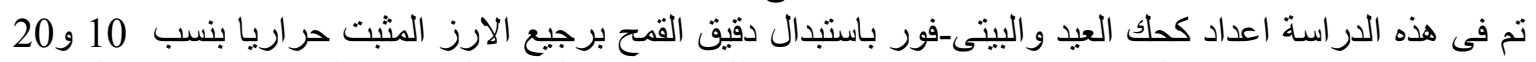

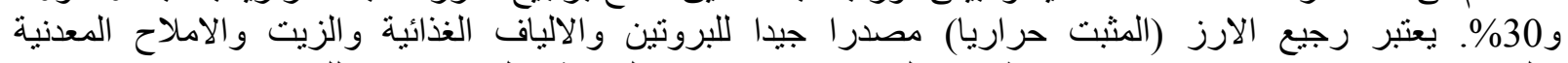

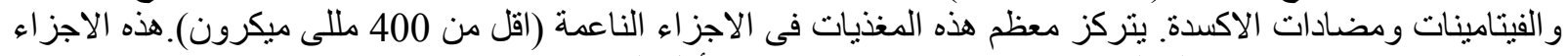

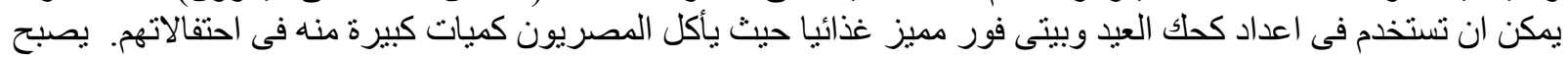

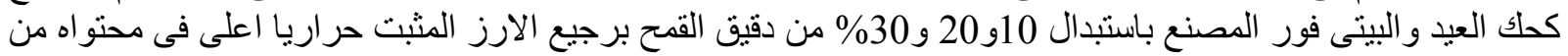

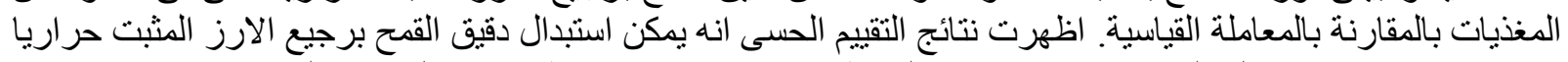

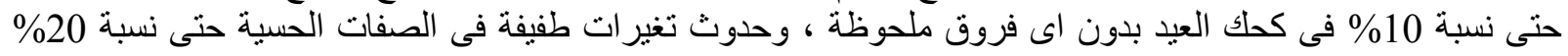

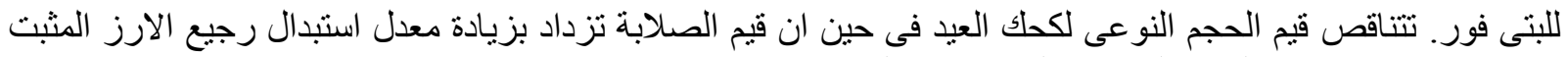

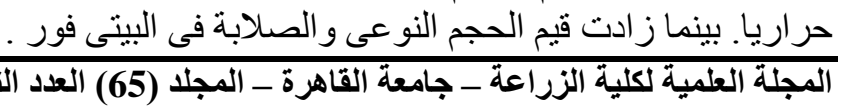

